\title{
Evolution of the fruit market in the city of Lavras-Minas Gerais- Brazil
}

\author{
José Clélio de Andrade ${ }^{1}$, Lair Victor Pereira ${ }^{2}$, Ângelo Albérico Alvarenga ${ }^{3}$, \\ Ester Alice Ferreira ${ }^{4}$, Paulo Márcio Norberto ${ }^{5}$ \\ Research Company of Minas Gerais - EPAMIG, Lavras, MG, Brazil, CP 176, CEP: 37200-000
}

\begin{abstract}
Fruit growing has achieved advances through the use of new technologies generated by research. In Brazil, it is one of the most prominent sectors in agribusiness, achieving significant results and generating business opportunities. In this way, the fruit market has grown considerably in the last decades, both in quantity and in quality. Allied to this, the changes in consumer behavior regarding food consumption has been responsible for the increase of the fruit market. The objective of this work was to know the evolution of the fruit trade in the city of Lavras, state of Minas Gerais, Brazil, in relation to the quantity sold, monetary value, losses in the gondolas of retail establishments and per capita consumption of the population of this city.
\end{abstract}

Keywords - Market, Fruits, Consumption, food, Brazil.

\section{INTRODUCTION}

Fruticulture is one of the most prominent sectors of Brazilian agribusiness. Through a wide variety of crops, produced all over the country and in different climates, fruit production achieves significant results and generates opportunities for Brazilian agribusiness. Brazil is the third largest producer of fruit in the world, behind only China and India, which shows the sector's relevance to the Brazilian economy, with 38.36 million tons produced in 2013, behind only China, with 137.6 million tons, and India, with 71.07 million tons (AGRONEGÓCIO, 2015).

Brazilian production is focused on tropical, subtropical and temperate fruits, thanks to its territorial extension, geographical position, soil and climatic conditions. According to the IBRAF (2013), fruit growing in Brazil occupied an area of 2.2 million hectares, moved US\$5.5 billion and employed 5.6 million people, representing $27 \%$ of the agricultural labor force from the country.

In this way the fruit market has grown considerably in the last decades, both in quantity and in quality. This was possible because of advances in research and development in the sector. In four decades, Brazil has passed from importer to exporter of some temperate fruits, such as apple. In the 1970s, the national production of this fruit represented only $10 \%$ of domestic consumption. Today, there are over 36,000 hectares producing high-quality apples, enough to serve the domestic market and even export (ANDRADE et al., 2012ab).

In addition to this, changes in consumer behavior regarding food consumption have been responsible for the increase in the fruit market (PIMENTEL; PIMENTEL, 2011).

Faced with this trend, the Center for Advanced Studies in Applied Economics, University of São Paulo (Cepea-USP), conducted a survey on fruit consumption in Brazil, where there was an average increase of approximately $4.38 \mathrm{~kg}$ per person per year, from 2005 to 2011 (SILVEIRA et al., 2011).

The objective of this work was to know the evolution of the fruit trade in the city of Lavras - MG - Brazil, in relation to the commercial volume, monetary value, percentage of losses in the gondolas and per capita consumption of fruits of the population.

\section{MATERIAL AND METHOD}

This research was carried out in three stages in the city of Lavras - MG - Brazil, the first in the months of August to July 2004/2005; The second in the months of August to July 2011/2012, and the third in the months of August to July 2014/2015, in the various networks of supermarkets, saloons and free-trade fairs.

The data collection was performed monthly, through a spreadsheet with questions about quantity sold, total value of consumer prices and percentage of losses in gondolas. The data collected were tabulated and analyzed monthly. 
The sampling of the number of establishments interviewed was carried out according to the criteria of Cochran (1965), in which locality with more than fifty commercial establishments the sample is $10 \%$, ten to forty of $20 \%$ and less than ten of $100 \%$. For this research carried out in the city of Lavras, Minas Gerais, Brazil, the sample was $100 \%$ of the four networks of supermarket establishments and ten retail establishments (Greenery).

\section{RESULT AND DISCUSSION}

According to the data presented in Figure 1, in the first stage (2004/2005), an average of $377.6 \mathrm{t}$ of fruits per month was traded, moving around US\$ 197,030.00, with a price Average of US\$ 0.52 per $\mathrm{kg}$ of fruit.

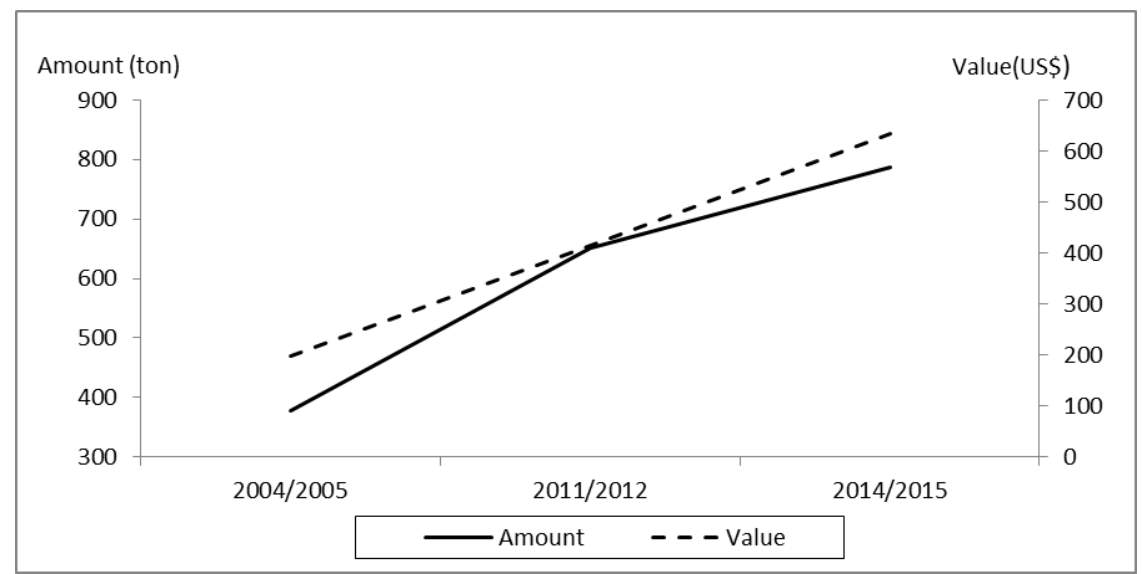

\section{FIGURE 1 - QUANTITY (T) AND VALUE (US\$) OF FRUITS TRADED IN LAVRAS FROM AUGUST TO JULY OF THE 2004/2005, 2011/2012 AND 2014/2015 PERIODS.}

In the second phase (2011/2012), there were $650.8 \mathrm{t}$ of fruits per month, moving US\$414,010.00 monthly, with an average price of US\$ 0.63 per kilo (ANDRADE et al., 2012a).

Finally, in the third stage, this average rose to $786.3 \mathrm{t}$ monthly, moving US\$ 634,890.00, per month at an average price of US\$ 0.80 per kilo of fruit.

According to the data presented, evolution of $72.35 \%$ from the first to the second stage and $108.23 \%$ from the first to the third stage, clearly shows the trend of increase in fruit consumption by the population, mainly motivated Aspects related to health and the search for a better quality of life.

In the last six years, the per capita consumption of fruit in Lavras rose from $47.76 \mathrm{~kg} / \mathrm{inhabitant} /$ year to $58.90 \mathrm{~kg} /$ inhabitant / year (ANDRADE et al., 2012ab). In that interval, consumption per capita had an increase of $11.14 \mathrm{~kg}$ per person per year, which was more than twice the average in Brazil, where there was an increase of $4.38 \mathrm{~kg}$ per person per year, according to Data published by Cepea-USP (SILVEIRA et al., 2011).

Comparing the evolution from the first to the third stage, per capita consumption increased from $47.76 \mathrm{~kg} / \mathrm{inhabitant} / \mathrm{year}$ (ANDRADE et al., 2012b) to $78.63 \mathrm{~kg} /$ inhabitant / year, representing an increase of $30,87 \mathrm{~kg} / \mathrm{hab} /$ year, ie an increase of $64.63 \%$ in per capita consumption.

The per capita consumption in 2010 in Brazil was $57.00 \mathrm{~kg} / \mathrm{hab} /$ year, in Italy, 114.00 and in Spain, $120.00 \mathrm{~kg} / \mathrm{hab} /$ year, according to FAO (2015).

In Lavras, although per capita consumption is higher than the national average, it is still below that observed in Italy and Spain (ANDRADE et al., 2012a). This fact can be explained by the increase in the supply of fruits in the retail market, as a consequence of the increase in the demand for the population, due to the behavioral changes of the population that started to look for healthier foods, together with an improvement of the purchasing power of the society in general, As well as the improvement of the supply and distribution of these products by the retail network with assiduity and punctuality.

The losses of the fruits in supermarket gondolas and sweets, went from 7.8\% (ANDRADE et al., 2012a), in the first stage, to $4.6 \%$ in the third stage, according to the report of the responsible for the hortifrúti section of the researched establishments. There was a reduction in losses from 64.24 to $40.48 \mathrm{t} /$ month, or $23.76 \mathrm{t} /$ month less, representing a saving in waste of $\mathrm{R} \$$ 
57,261.50 per month. This is due to the efforts made by the management of Central of Supply of the State of Minas Gerais CeasaMinas in the logistics of distribution to the final consumer.

Table 1 shows the data of the main fruits commercialized in the city of Lavras, MG, in the third stage of this research.

TABLE 1

MOST MARKETED FRUITS (T) IN LAVRAS - MG, BRAZIL, FROM AUGUST 2014 TO JANUARY 2015

\begin{tabular}{|c|c|c|c|c|c|c|c|}
\hline Fruit/Month & Aug/14 & Set/14 & Oct/14 & Nov/14 & Dec/14 & Jan/15 & Average \\
\hline Silver banana & 92,79 & 109,66 & 109,93 & 102,24 & 104,72 & 94,38 & 102,29 \\
\hline Banana nanica & 28,29 & 27,09 & 33,30 & 32,79 & 47,85 & 53,46 & 37,13 \\
\hline Orange pear & 105,85 & 109,66 & 121,90 & 97,99 & 92,13 & 94,60 & 103,70 \\
\hline National apple & 44,52 & 41,29 & 56,05 & 33,87 & 59,30 & 35,44 & 45,08 \\
\hline Papaya formosa & 19,50 & 24,29 & 19,37 & 15,86 & 13,73 & 21,50 & 19,04 \\
\hline Papaya amazonas & 15,01 & 18,70 & 16,37 & 20,15 & 16,14 & 22,34 & 18,12 \\
\hline Pear pineapple & 20,86 & 18,92 & 18,72 & 24,01 & 30,60 & 18,29 & 21,90 \\
\hline Pink grape & - & - & - & - & 26,14 & - & - \\
\hline Manga palmer & - & - & - & - & - & 26,52 & - \\
\hline Sub-total & 326,82 & 349,58 & 375,64 & 326,91 & 364,47 & 340,01 & 347,24 \\
\hline others & 419,28 & 433,32 & 435,16 & 433,49 & 467,93 & 445,39 & 439,10 \\
\hline TOTAL & 746,00 & 782,90 & 810,80 & 760,40 & 832,40 & 785,40 & 786,34 \\
\hline
\end{tabular}

" Subtotal for banana, orange, apple, papaya and pineapple

The banana is the most commercialized fruit, with a monthly average of $139.42 \mathrm{t}$, of which the cultivar Silver contributes $102.29 \mathrm{t}$ and Nanica, with $37.13 \mathrm{t}$.

The second most traded fruit is the 'Pêra' orange, with a monthly average of $103.70 \mathrm{t}$, followed by the national apple with $45.08 \mathrm{t}$ and the papaya with $37.16 \mathrm{t}$, being $19.04 \mathrm{t}$ of the papaya 'Formosa', and $18.12 \mathrm{t}$ of the 'Amazonas' papaya.

In December 2014, the 'Rosada' grape was the 5th placed, with 26.14 t, and in January 2015, this position was occupied by the 'Palmer', with $26.54 \mathrm{t}$.

In the three steps surveyed, it is verified that the month of December was the month of greatest fruit supply in the city of Lavras. It can be said that this event is due to the greater supply of fruits, accompanied by the greater demand of fruits by the population, a factor motivated by the Christmas festivities and also by the increase of income, with the receipt of the 13th salary.

As for the increase in the volume of marketed fruit, it can be said that it is a consequence of the increase of productivity and quality, as well as the constant supply of these products during all months of the year. This offer, in turn, is provided by the technological development resulting from the results of continuous scientific research, which has made possible the advancement of fruit growing in the various geographic regions of the State of Minas Gerais and Brazil.

\section{CONCLUSION}

The commercialization of fruit in Lavras has increased simultaneously to the increase of the consumption and the supply of fruits with quality, assiduity and punctuality;

The average price of fruit has also increased, in line with inflation;

Losses in facilities decreased as a result of more efficient distribution logistics;

Technological development has provided better quality fruit during all months of the year, favoring increased consumption, which has also been driven by changing consumer habits.

\section{REFERENCES}

[1] AGRONEGÓCIO: Fruticultura: Boletim de Inteligência. [S.1.] Sebrae, out. 2015. Available: http://www.bibliotecas.sebrae.com.br/chronus/ARQUIVOS_CHRONUS/bds/bds.nsf/64ab878c176e5103877bfd3f92a2a68f/\$File/57 91.pdf. Accessed: may 2017 
[2] ANDRADE, J.C. et al. Mercado de frutas em Lavras - MG. Lavras: EPAMIG-CTSM, 2012a, 3p. (EPAMIG-CTSM. Circular Técnica, 149).

[3] ANDRADE, J.C. et al. Performance do comercio de frutas em Lavras - MG, nos períodos de 2004/2005 a 2011/2012. In. : CONGRESSO BRASILEIRO DE FRUTICULTURA, 22, Bento Gonçalves. Anais... Bento Gonçalves: Sociedade Brasileira de Fruticultura, 2012b. p. $2606-2610$.

[4] COCHRAN, W. G. The Planning of Observational Studies of Human Populations. Journal of the Royal Statistical Society. Serie A (General), Vo. 128, № 2 (1965), pp. 234-266.

[5] FAO. Faostat. Rome. Available in: http://faostat.fao.org Accessed:: december 2015.

[6] INSTITUTO BRASILEIRO DE FRUTAS - IBRAF, 2010. Produção Brasileira de Frutas, 2009. Disponível em: Accessed:: december 2015.

[7] PIMENTEL, P.M.; PIMENTEL, L.P. Tendências do mercado de frutas de uso imediato. Pelotas: Embrapa Clima Temperado, [2011]. Available: www.ceinfo.cnpct.embrapa/artigo contexto.plep?op=1\&. Accessed: may 2015.

[8] SILVEIRA, J. et al. Quem é o consumidor brasileiro de frutas e hortaliças? Hortifruti Brasil, Piracicaba, ano 10, n.103, p.8-23, jul. 2011. Available: www.cepa.esalq.usp.br/hfbrasil/edicoes/103/full.pdf. Accessed: may 2017. 